Photochemical \&

Photobiological Sciences

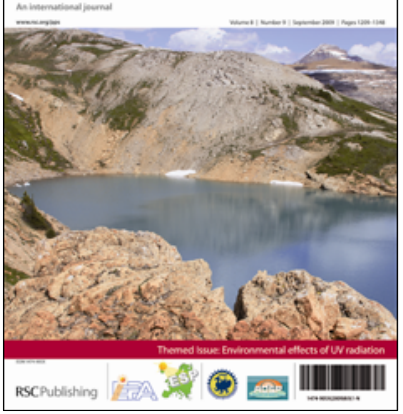

Perspectives
This article is published as part of a themed issue of

Photochemical \& Photobiological Sciences on

Environmental effects of UV radiation

Guest edited by Ruben Sommaruga

Published in issue 9, 2009

Effects of ultraviolet radiation on the productivity and composition of freshwater phytoplankton communities

J. W. Harrison and R. E. H. Smith, Photochem. Photobiol. Sci., 2009, 8, 1218

UV-B absorbing compounds in present-day and fossil pollen, spores, cuticles, seed coats and wood: evaluation of a proxy for solar UV radiation

J. Rozema, P. Blokker, M. A. Mayoral Fuertes and R. Broekman, Photochem. Photobiol. Sci., 2009, 8, 1233

Differences in UV transparency and thermal structure between alpine and subalpine lakes: implications for organisms

K. C. Rose, C. E. Williamson, J. E. Saros, R. Sommaruga and J. M. Fischer, Photochem. Photobiol. Sci., 2009, 8, 1244

Interactions between the impacts of ultraviolet radiation, elevated $\mathrm{CO}_{2}$, and nutrient limitation on marine primary producers

J. Beardall, C. Sobrino and S. Stojkovic, Photochem. Photobiol. Sci., 2009, 8, 1257

Effects of ultraviolet radiation on pigmentation, photoenzymatic repair, behavior, and community ecology of zooplankton

L.-A. Hansson and S. Hylander, Photochem. Photobiol. Sci., 2009, 8, 1266

Effects of solar ultraviolet radiation on coral reef organisms

A. T. Banaszak and M. P. Lesser, Photochem. Photobiol. Sci., 2009, 8, 1276

Does ultraviolet radiation affect the xanthophyll cycle in marine phytoplankton? W. H. van de Poll and A. G. J. Buma, Photochem. Photobiol. Sci., 2009, 8, 1295

Papers

Photosynthetic response of Arctic kelp zoospores exposed to radiation and thermal stress M. Y. Roleda, Photochem. Photobiol. Sci., 2009, 8, 1302

Remarkable resistance to UVB of the marine bacterium Photobacterium angustum explained by an unexpected role of photolyase

S. Matallana-Surget, T. Douki, R. Cavicchioli and F. Joux, M. Y. Roleda, Photochem. Photobiol. Sci., 2009, 8, 1313

Alteration of chromophoric dissolved organic matter by solar UV radiation causes rapid changes in bacterial community composition

C. Piccini, D. Conde, J. Pernthaler and R. Sommaruga, Photochem. Photobiol. Sci., 2009, 8, 1321

Quality of UVR exposure for different biological systems along a latitudinal gradient M. Vernet, S. B. Diaz, H. A. Fuenzalida, C. Camilion, C. R. Booth, S. Cabrera, C. Casiccia, G. Deferrari, C. Lovengreen, A. Paladini, J. Pedroni, A. Rosales and H. E. Zagarese, Photochem. Photobiol. Sci., 2009, 8, 1329 


\title{
Photosynthetic response of Arctic kelp zoospores exposed to radiation and thermal stress $\dagger$
}

\author{
Michael Y. Roleda* \\ Received 19th January 2009, Accepted 6th March 2009 \\ First published as an Advance Article on the web 19th March 2009 \\ DOI: 10.1039/b901098j
}

Zoospores of Arctic kelp species, Alaria esculenta, Laminaria digitata and Saccharina latissima were exposed to different temperature $\left(2{ }^{\circ} \mathrm{C}\right.$ to $\left.19^{\circ} \mathrm{C}\right)$ and radiation (photosynthetically active radiation $(\mathrm{PAR}=\mathrm{P}), \mathrm{PAR}+\mathrm{UV}-\mathrm{A}(\mathrm{PA})$, and PAR + UV-A + UV-B (PAB)) conditions in the laboratory. Species-specific responses to the combined effect of light and temperature stress showed sensitivity in the order $S$. latissima $>$ L. digitata $>$ A. esculenta. The optimum temperature range for photosynthesis in different Arctic kelp species' zoospores was between $7-13{ }^{\circ} \mathrm{C}$, temperatures higher than in the natural environment. Short-term response to increasing temperature was non-lethal while moderate temperature increase had an ameliorating effect on the overall biological effect of UVR; where the lowest photoinhibition was observed at $13{ }^{\circ} \mathrm{C}$ under $\mathrm{PAB}$ and higher photosynthetic recovery was observed in UVR-pre-exposed zoospores at $7-13{ }^{\circ} \mathrm{C}$ compared to $2{ }^{\circ} \mathrm{C}$. Above the temperature optima, continued cultivation under high temperature had a negative impact on the recovery of photoinhibition. The higher capacity for non-photochemical quenching (NPQ) in A. esculenta and L. digitata helped to regulate and protect photosynthesis under light and temperature stress compared to $S$. latissima. The investigated Arctic kelp species may be able to locally survive under the influence of UVR at a certain range of temperature increase but the southernmost distribution range of the species may shift to higher latitudes; although natural selection may result in genotypes adapted to stressful environment.

\section{Introduction}

The present state of the world climate is marked by continued global warming, further declines in Arctic sea ice and severe stratospheric ozone depletion, especially in the Antarctic; all notable climate anomalies and events occurring in the year $2006 .^{1}$ The global climate change, which is anthropogenic in origin, is progressing at an unprecedented speed with a projected increase in global mean temperature of up to $6{ }^{\circ} \mathrm{C}$ over this century. ${ }^{2,3}$ Moreover, the "Arctic amplification" phenomenon has brought about near-surface warming in the Arctic twice as large as the global average over recent decades. ${ }^{4,5}$ Consequently, the decrease in Arctic sea ice cover and surface albedo has altered the solar radiation forcing on the Arctic atmosphere-ice-ocean system allowing more solar heating of the upper ocean. ${ }^{6}$

Various North Atlantic kelp species have broad latitudinal distribution occurring as far south as the $16^{\circ} \mathrm{C}$ summer isotherm on the coasts of Brittany and Portugal and extend north towards the Arctic. ${ }^{7,8}$ The species-specific temperature tolerance and temperature ranges for survival, growth, and reproduction determine their autecology and biogeography.,10 Consequently, changing water temperatures can trigger shifts in their distributional boundaries ${ }^{11-13}$ and geographic distribution. On the other hand, development of ecotypes is possible ${ }^{14}$ allowing disjunct refuge populations to thrive even in stressful environments.

Institute for Polar Ecology, University of Kiel, Wischhofstrasse 1-3, Bldg. 12, D-24148, Kiel, Germany. E-mail: mroleda@ipoe.uni-kiel.de; Fax: +49 431 6001210; Tel: +494316001235

$\dagger$ This article was published as part of the themed issue on "Environmental effects of UV radiation".
A significant depletion of the Arctic ozone layer occurred in some years (e.g. 1999-2000, 2001-2002, 2004-2005) during the late winter/spring period (January-April) ${ }^{15-17}$ coinciding with the reproductive peaks of most Arctic kelp species. Biologically significant ultraviolet radiation (UVR) can penetrate to $5 \mathrm{~m}$ depth in Arctic waters that may change in the future due to the interactions between global warming and ozone depletion. ${ }^{18}$ Even under non-depleted ozone conditions, UV-B still presents potential negative impacts to photosynthetic organisms.

When exposed to light intensities exceeding their photosynthetic capacity, regulated thermal dissipation of absorbed light is without question the keystone of photoprotection. ${ }^{19}$ Moreover, oxygenic photoautotrophic organisms have evolved a highly specialized repair mechanism that restores the functional status of photosystem II (PSII) and prevents the accumulation of photodamage. ${ }^{20} \mathrm{UV}$ contributes to further photodamage by inactivation of the oxygenevolving complex and photochemical reaction centers of the PSII ${ }^{21}$ which delays photosynthetic recovery in Arctic kelp zoospores. ${ }^{22}$

The photophosphorylation and electron transport enzymes as well as plastoquinone diffusion enzyme are temperature dependent. Variation in temperature can, therefore, affect the light harvesting efficiency ( $\alpha$, the slope of the initial light-limited region of the photosynthesis-irradiance curve) of phototrophs. ${ }^{23}$ The low-temperature limitation of electron transport can cause a reduction in the ability of phototrophs to use light. Consequently, the excess light energy may damage the PSII apparatus resulting in photoinhibition. ${ }^{23}$ Conversely, the thermolabile nature of PSII is related to the reduction in photosynthesis at temperatures above temperature optimum. ${ }^{24}$ The thermal stability of PSII effectively determines the upper temperature tolerance of photosynthesis. 
Temperature can also modify the effects of UVR on photosynthesis by affecting the rate of repair. The ameliorating effects of increased temperature under UVR on phytoplankton have been demonstrated for growth in cyanobacteria, diatoms and natural lake assemblages. ${ }^{25-28}$ There are also reports showing the beneficial effects of increased temperature on the germination rate, cell number, photosynthesis $\left(F_{\mathrm{v}} / F_{\mathrm{m}}\right)$, and DNA damage repair rates of macroalgae. ${ }^{29-32}$

Zoospore germination in the Arctic population of Alaria esculenta, Laminaria digitata and Saccharina latissima was optimal between 2 and $12{ }^{\circ} \mathrm{C}$, and impaired at $18{ }^{\circ} \mathrm{C} .{ }^{33}$ Significant additional negative UV-B effect was observed at 2 and $12{ }^{\circ} \mathrm{C}$ in L. digitata and at $12{ }^{\circ} \mathrm{C}$ in $S$. latissima, but not in $A$. esculenta. ${ }^{33}$ Whether the temperature optima for photosynthesis are the same or higher than the optimum temperatures for growth (or germination) in different Arctic kelp zoospores is yet to be studied. This study aims to determine: (a) the light harvesting efficiency and short-term response of Arctic kelp zoospore photosynthesis to increasing temperature; (b) the role of temperature on photoinhibition and recovery of photosynthesis under PAR and UVR; and (c) the photoprotective function of nonphotochemical quenching processes in thermal dissipation. The results are discussed with respect to possible changes in geographic distribution of the studied species.

\section{Experimental}

\section{Materials and methods}

Algal material. Fertile sporophytes of Alaria esculenta (Linnaeus) Greville, Laminaria digitata (Hudson) Lamouroux and Saccharina latissima (Linnaeus) C.E. Lane, C. Mayes, Druehl \& G.W. Saunders were collected between May and June 2006 by SCUBA divers in Kongsfjorden at Prins Heinrichøya or Blomstrandhalvøya close to $\mathrm{Ny}$ Ålesund (Spitsbergen, $78^{\circ} 55^{\prime} \mathrm{N}$, $\left.011^{\circ} 56^{\prime} \mathrm{E}\right)$. Blades with sori were excised from five different individuals per species (representing the five replicates), cleaned of epiphytes, blotted with tissue paper and kept in darkness in a moist chamber at $0{ }^{\circ} \mathrm{C}$ overnight for a maximum of 2 days. To induce rapid release of zoospores, sori were immersed in 5-10 ml filtered $\left(0.2 \mu \mathrm{m}\right.$ pore size) seawater at $\pm 15{ }^{\circ} \mathrm{C}$ and exposed to natural light close to a window. Initial density of zoospores in all experimental units was standardized by measuring initial $\mathrm{Chl} a$ fluorescence $\left(F_{0}\right)$ between $800-1000 \mathrm{mV}$. Stock suspensions were diluted with filtered seawater to obtain the desired fluorescence among the five replicates.

\section{Temperature-controlled rooms and radiation treatments}

Four temperature-controlled rooms were established at $2^{\circ}, 7^{\circ}$, $13^{\circ}$ and $19{ }^{\circ} \mathrm{C}$. Inside each chamber, white fluorescent tubes (Osram, L65 Watt/25S, Munich, Germany) and UVA-340 fluorescent tubes (Q-Panel, Cleveland, OH, USA) were used to provide photosynthetically active radiation (PAR, 400-700 nm) and ultraviolet radiation (UVR, 280-400 nm), respectively. To cut off different wavelength ranges from the spectrum emitted by the fluorescent tubes, cell culture dishes were covered with one of the following filters: Ultraphan transparent (Digefra $\mathrm{GmbH}$, Germany), Folanorm (Folex GmbH, Germany) or Ultraphan
URUV farblos corresponding to the PAR + UV-A + UV-B (PAB), PAR + UV-A (PA) and PAR (P) treatments, respectively. Ultraviolet radiation was measured using a Solar Light PMA 2100 radiometer equipped with the UV-A sensor PMA 2110 and the UV-B Sensor PMA 2106 (Solar Light, Philadelphia, USA). Adjusted ultraviolet radiation below the cut-off filters was $4.34 \mathrm{~W}$ $\mathrm{m}^{-2} \mathrm{UV}-\mathrm{A}$ and $0.40 \mathrm{~W} \mathrm{~m}^{-2} \mathrm{UV}-\mathrm{B}$. The available PAR measured using a cosine quantum sensor attached to a LI-COR data logger (LI-1000, LI-COR Biosciences, Lincoln, Nebraska, USA) was $22 \mu \mathrm{mol}$ photons $\mathrm{m}^{-2} \mathrm{~s}^{-1}\left(\sim 4.73 \mathrm{~W} \mathrm{~m}^{-2}\right)$. The maximum daily average irradiance in air in summer (June and July) is $790 \mu \mathrm{mol}$ photons $\mathrm{m}^{-2} \mathrm{~s}^{-1}$ PAR, $17 \mathrm{~W} \mathrm{~m}^{-2} \mathrm{UV}-\mathrm{A}$ and $0.30 \mathrm{~W} \mathrm{~m}^{-2} \mathrm{UV}-\mathrm{B} .{ }^{34}$

\section{Chlorophyll fluorescence measurements}

Photosynthetic efficiencies of zoospores were measured as variable fluorescence of PSII using a Water Pulse Amplitude Modulation fluorometer (Water-PAM) consisting of Emitter-Detector Unit Water-ED and PAM-Control Universal Control Unit connected to a PC operated with WinControl software (Heinz Walz $\mathrm{GmbH}$, Effeltrich, Germany). ${ }^{22}$ Immediately after adjustment of spore density, the suspension was filled into the $5 \mathrm{ml}$ quartz cuvettes and the optimum quantum yield $\left(F_{\mathrm{v}} / F_{\mathrm{m}}\right)$ was measured inside the Emitter-Detector Unit at time zero $(n=5)$. After 3 min of dark incubation, $F_{0}$ was measured with a red measuring light pulse $\left(\sim 0.3 \mu \mathrm{mol}\right.$ photons $\left.\mathrm{m}^{-2} \mathrm{~s}^{-1}, 650 \mathrm{~nm}\right)$, and $F_{\mathrm{m}}$ was determined with a $800 \mathrm{~ms}$ completely saturating red light pulse $(\sim 2750 \mu \mathrm{mol}$ photons $\left.\mathrm{m}^{-2} \mathrm{~s}^{-1}, 650 \mathrm{~nm}\right)$.

Rapid photosynthesis (in terms of relative electron transport rate, $\left.\mathrm{rETR}=\mathrm{PFR} \times \Delta F / F_{\mathrm{m}}{ }^{\prime}\right)$ versus irradiance $(E)$ curves $(\mathrm{P}-\mathrm{E}$ curve) of zoospore suspension were measured in triplicates using a Water PAM device (Walz, Effeltrich, Germany) described by Roleda et al. ${ }^{22}$ Samples were exposed to actinic light for $30 \mathrm{~s}$ at each of 8 points of increasing intensity (4-69 $\mu \mathrm{mol}$ photons $\mathrm{m}^{-2} \mathrm{~s}^{-1}$ ). The hyperbolic tangent model of Jassby and Platt ${ }^{35}$ was used to estimate P-E curve parameters described as:

$$
\mathrm{rETR}=\mathrm{rETR}_{\max } \times \tanh \left(\alpha \times E_{\mathrm{PAR}} \times \mathrm{rETR}_{\max }{ }^{-1}\right)
$$

where $\mathrm{rETR}_{\max }$ is the maximum relative electron transport rate, tanh is the hyperbolic tangent function, $\alpha$ is the electron transport efficiency and $E$ is the photon fluence rate of PAR. Curve fit was calculated with the Solver Module of MS-Excel using the least squares method comparing differences between measured and calculated data. The saturation irradiance for electron transport $\left(E_{\mathrm{k}}\right)$ was calculated as the light intensity at which the initial slope of the curve $(\alpha)$ intercepts the horizontal asymptote $\left(\mathrm{rETR}_{\max }\right)$.

Controls measured at time zero were filled into corresponding culture dishes $(35 \mathrm{~mm} \times 10 \mathrm{~mm}$; CorningTM, Corning Inc., NY, USA). To evaluate the effect of different radiation treatments (3 levels: P, PA and PAB) under different temperatures (4 levels: $2^{\circ}, 7^{\circ}, 13^{\circ}$ and $19^{\circ} \mathrm{C}$ ), samples of fresh zoospore suspension (not exceeding $1 \mathrm{~h}$ after release) were filled into each culture dishes. Samples corresponding to the 5 replicates were exposed to each treatment combination for $8 \mathrm{~h}$. After treatment, $F_{\mathrm{v}} / F_{\mathrm{m}}$ was determined and the suspension was returned to the same culture dish and cultivated under dim white light $(10 \pm 1 \mu \mathrm{mol}$ photons $\mathrm{m}^{-2} \mathrm{~s}^{-1}$ ) at the same temperature for recovery. The controls were also maintained at the same dim light condition and $F_{\mathrm{v}} / F_{\mathrm{m}}$ was repeatedly measured in time-series. Measurements of photosynthetic 
recovery of high PAR and UVR-treated samples were made after $48 \mathrm{~h}$ in dim light condition. The non-photochemical-quenching (NPQ) parameter after exposure to different combination of temperature and light treatments was derived according to the equation: $\mathrm{NPQ}=\left(F_{\mathrm{m}}-F_{\mathrm{m}}{ }^{\prime}\right) / F_{\mathrm{m}}{ }^{\prime}$. Settled and germinating spores were slowly resuspended by sucking and jetting the medium against the bottom of the culture dish using Eppendorf pipettes.

\section{Statistical analysis}

Raw absolute data were tested for homogeneity (Levene Statistics) of variance. Corresponding transformations (square roots) were made to heteroskedastic data. $F_{\mathrm{v}} / F_{\mathrm{m}}$ were tested using analyses of variance (ANOVA, $P<0.05$ ) followed by Duncan's multiple range test (DMRT, $P<0.05$ ). Statistical analyses were performed using SPSS software (Chicago, IL, USA).

\section{Results}

The rapid photosynthesis-irradiance (P-E) curve parameter estimates of freshly-released zoospores measured in $7^{\circ} \mathrm{C}$ temperaturecontrolled room showed comparable $\mathrm{rETR}_{\max }$ (ANOVA, $P=$ 0.603), $\alpha(P=0.333)$ and $E_{\mathrm{k}}(P=0.394)$ between different kelp species (Fig. 1); with values ranging between $0.66-1.20$ rel. units, $0.08-0.16$, and 9-16 $\mu \mathrm{mol}$ photons $\mathrm{m}^{-2} \mathrm{~s}^{-1}$, respectively. After $4 \mathrm{~h}$ incubation of zoospores of Saccharina latissima at $2^{\circ}, 7^{\circ}$ and $13^{\circ} \mathrm{C}$, a temperature-dependent variation in light harvesting efficiency and electron transport were observed between treatments (Fig. 2, Table 1). Analysis of variance with individual source sporophytes as a random variable showed temperature and sporophytespecific variation in $\mathrm{rETR}_{\max }$ and $\alpha$ (ANOVA, $P<0.05$ ) but not the $E_{\mathrm{k}}$ (ANOVA, $P>0.05$ ). The $\mathrm{rETR}_{\max }$ and $\alpha$ were highest in $13{ }^{\circ} \mathrm{C}(1.6 \pm 0.8$ and $0.1 \pm 0.04$, respectively) and lowest in $2{ }^{\circ} \mathrm{C}(0.6 \pm 0.3$ and $0.04 \pm 0.02$, respectively $)$.

The optimum quantum yield of zoospores for up to $48 \mathrm{~h}$ after release and subsequent incubation at different temperature under low white light $\left(10 \mu \mathrm{mol}\right.$ photons $\left.\mathrm{m}^{-2} \mathrm{~s}^{-1}\right)$ showed decreasing $F_{\mathrm{v}} / F_{\mathrm{m}}$ in all species at $19{ }^{\circ} \mathrm{C}$ with $L$. digitata and $S$. latissima showing adverse response already after $4 \mathrm{~h}$ and $8 \mathrm{~h}$ incubation, respectively (Fig. 3). Optimum $F_{\mathrm{v}} / F_{\mathrm{m}}$ was measured at $13{ }^{\circ} \mathrm{C}$ in all species. The $F_{\mathrm{v}} / F_{\mathrm{m}}$ measured at $2{ }^{\circ} \mathrm{C}$ was compromised but sustained at a minimum up to $48 \mathrm{~h}$. Conversely, $F_{\mathrm{v}} / F_{\mathrm{m}}$ progressively decreased

Table 1 Individual sporophyte-specific vitality in Saccharina latissima impacts the maximum photosynthetic electron transport rate $\left(\mathrm{rETR}_{\max }\right)$, and light harvesting and photosynthetic conversion efficiency $(\alpha)$ of their respective zoospores after $4 \mathrm{~h}$ acclimation to different culture temperature

\begin{tabular}{lllll}
\hline & & \multicolumn{3}{l}{ Temperature } \\
\cline { 3 - 5 } P-E parameter & Sporophyte & $2{ }^{\circ} \mathrm{C}$ & $7{ }^{\circ} \mathrm{C}$ & $13{ }^{\circ} \mathrm{C}$ \\
\hline rETR $_{\max }$ & 1 & 0.404 & 0.614 & 0.985 \\
& 2 & 0.880 & 2.057 & 2.571 \\
& 3 & 0.482 & 1.089 & 1.352 \\
$\alpha$ & 1 & & & \\
& 2 & 0.023 & 0.076 & 0.080 \\
& 3 & 0.053 & 0.108 & 0.145 \\
$E_{\mathrm{k}}$ & 1 & & 0.074 & 0.086 \\
& 2 & 17.5 & 8.1 & 12.3 \\
& 3 & 16.6 & 19.1 & 17.8 \\
& & 12.6 & 14.8 & 15.8 \\
\hline
\end{tabular}

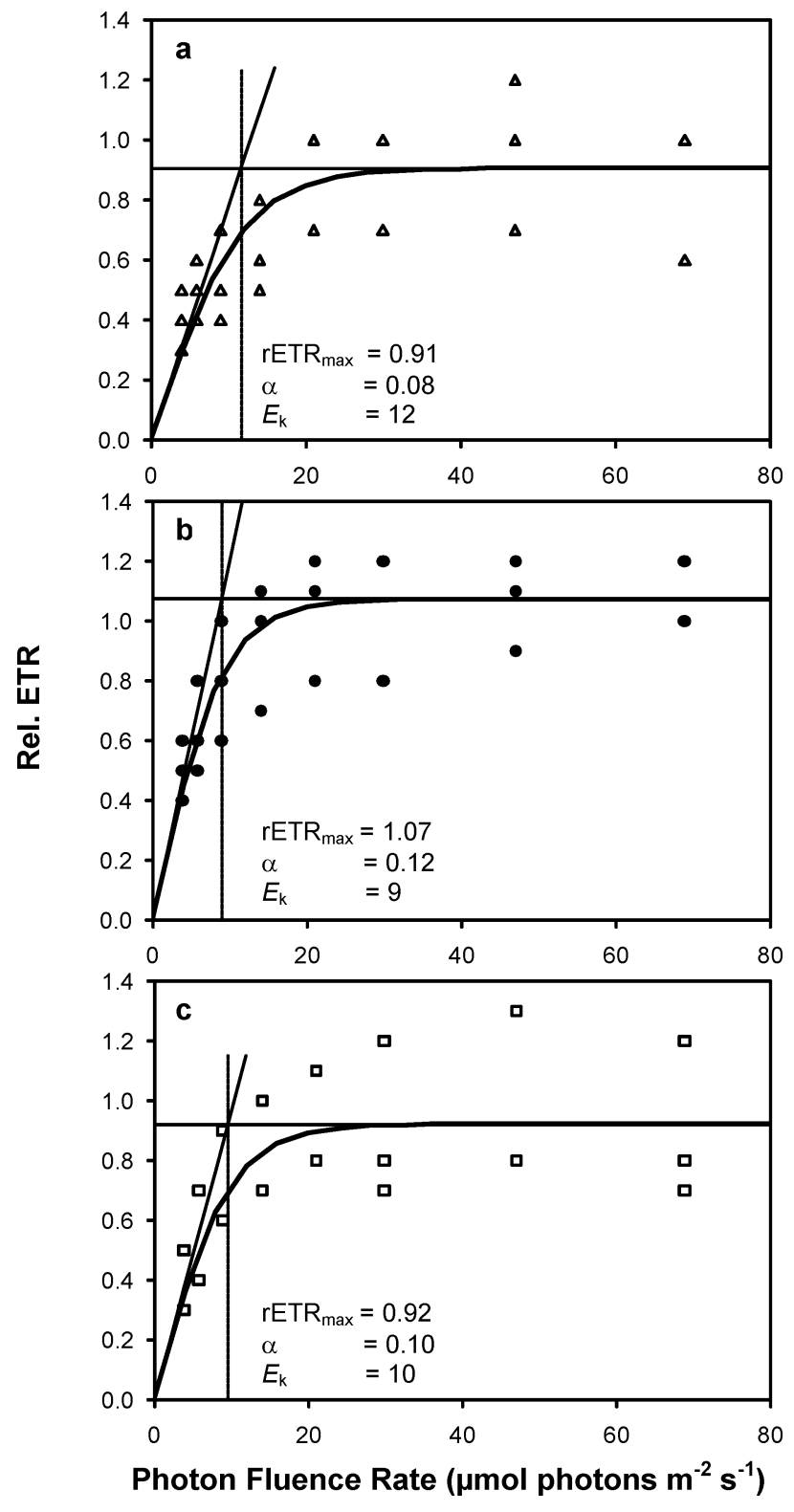

Fig. 1 Rapid light curves (photosynthesis-irradiance, P-E curves) of zoospores in (a) Alaria esculenta, (b) Laminaria digitata and (c) Saccharina latissima $(n=3)$ immediately after release from the sori. PFR is the respective photon fluence rate of actinic light ( $30 \mathrm{~s}$ exposure) and rETR is the relative electron transport rate, an index of light harvesting and subsequent charge separation in PSII and PSI initiating electron transport and production of NADPH and ATP. Saturating irradiance $\left(E_{\mathrm{k}}\right)$ is estimated as the point at which the initial slope $(\alpha)$ crosses maximum photosynthesis $\left(\mathrm{rETR}_{\max }\right.$ ) using the hyperbolic tangent model of Jassby and Platt, 1976. ${ }^{35}$ Thick solid lines are the calculated mean curve fit for each species.

at $19{ }^{\circ} \mathrm{C}$, with $<50 \%$ yield after $24 \mathrm{~h}$ in all species and $<75 \%$ to non detectable in S. latissima after $48 \mathrm{~h}$ incubation. Repeated measure analysis of variance (RMANOVA, $P<0.05$ ) showed significant differences between species, temperature and their interaction. The Posthoc Duncan's multiple range test (DMRT, $P=0.05$ ) showed species-specific photosynthetic performance in kelp zoospores, $A$. esculenta $(A e)>$ L. digitata $(L d)>S$. latissima $(S l)$ while optimum photosynthesis temperature was at $13{ }^{\circ} \mathrm{C}>7{ }^{\circ} \mathrm{C}>2{ }^{\circ} \mathrm{C}>19^{\circ} \mathrm{C}$. 


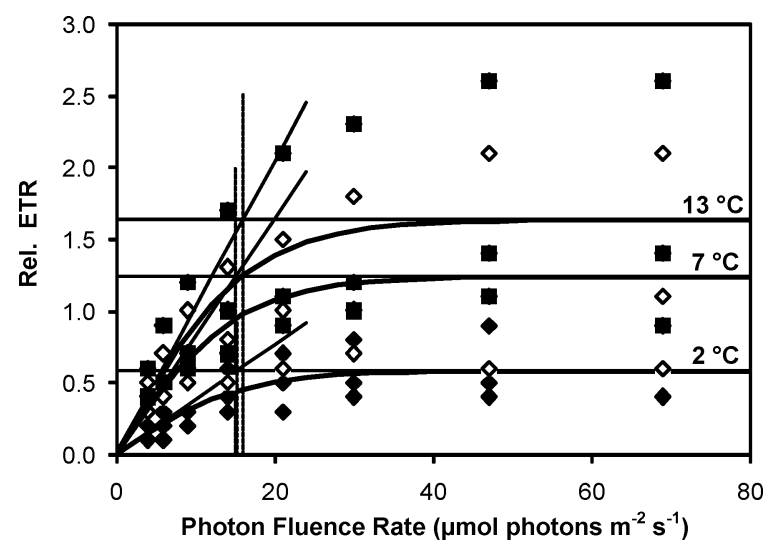

Fig. 2 Rapid light curves (photosynthesis-irradiance, P-E curves) of Saccharina latissima zoospores after $4 \mathrm{~h}$ incubation at different temperatures $\left(2{ }^{\circ} \mathrm{C} \diamond, 7^{\circ} \mathrm{C} \diamond\right.$, and $13{ }^{\circ} \mathrm{C}$ ) maintained under low white light $(10 \mu \mathrm{mol}$ photons $\left.\mathrm{m}^{-2} \mathrm{~s}^{-1}\right)$. PFR is the respective photon fluence rate of actinic light and rETR is the relative electron transport rate. Thick solid lines are the mean curve fits for each temperature treatment calculated using the hyperbolic tangent equation. Spread of measured data points revealed individual-specific vitality of zoospores released from each sporophyte as shown in Table 1.

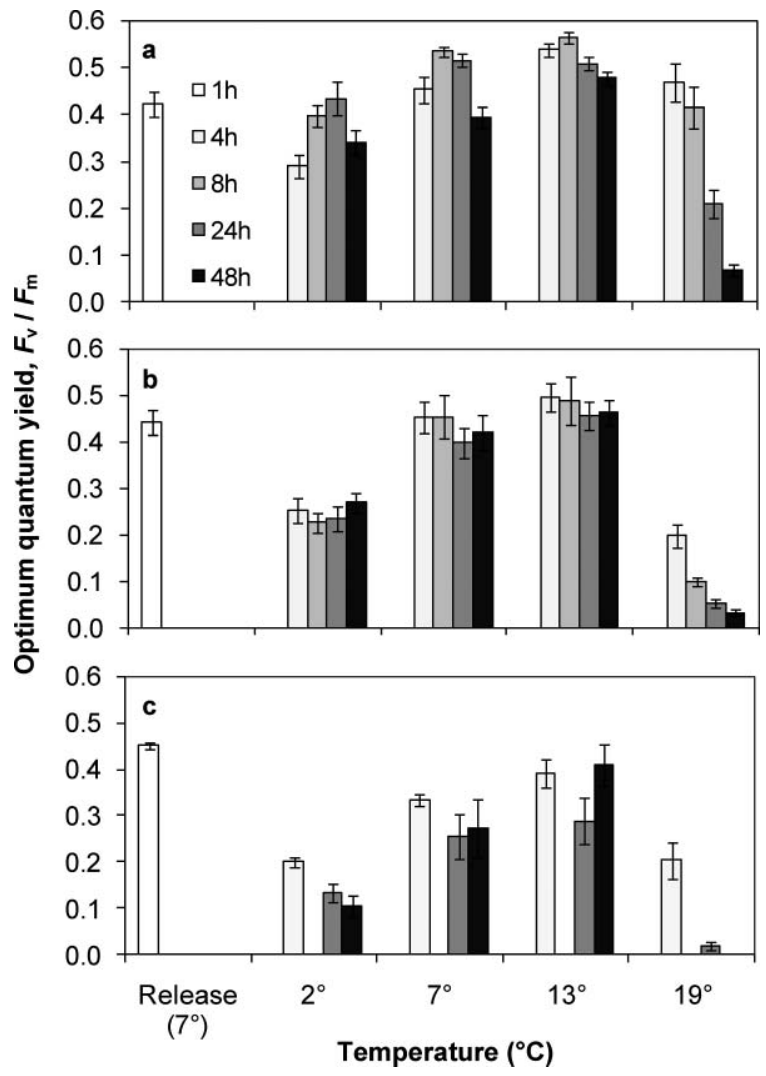

Fig. 3 Time series measurements on the mean optimum quantum yield $\left(F_{\mathrm{v}} / F_{\mathrm{m}}\right)$ of zoospores in (a) Alaria esculenta, (b) Laminaria digitata and (c) Saccharina latissima cultivated in different temperatures under low PAR $\left(10 \mu \mathrm{mol}\right.$ photons $\left.\mathrm{m}^{-2} \mathrm{~s}^{-1}\right)$. Error bars are SEs $(n=5)$. Repeated measure analysis of variance, RMANOVA, is shown in Table 3.

Exposure to different combination of experimental light and temperature treatments depressed the $F_{\mathrm{v}} / F_{\mathrm{m}}$ in all species after $8 \mathrm{~h}$ incubation (Table 2). Generally, $F_{\mathrm{v}} / F_{\mathrm{m}}$ was lowest at $2{ }^{\circ} \mathrm{C}$ and at all temperature regimes under the whole light spectrum (PAB). Photosynthetic performance expressed as percent photoinhibition showed highest inhibition of photosynthesis at $2{ }^{\circ} \mathrm{C}$ in all kelp species under all light treatments (Fig. $4 \mathrm{a}-\mathrm{c}$ ). Under P treatment, photoinhibition decreased with increasing temperature in $A$. esculenta (Fig. 4a). In L. digitata and S. latissima, photoinhibition was lowest at $13{ }^{\circ} \mathrm{C}$ (Fig. 4b, c). Photoinhibition under PA was highest at the temperature extremes, $2{ }^{\circ} \mathrm{C}$ and $19{ }^{\circ} \mathrm{C}$, in both $L$. digitata and $S$. latissima; while $A$. esculenta was more photoinhibited at the lower temperature extreme. A similar trend was observed under PAB in all species but with relatively lower photoinhibition at $13{ }^{\circ} \mathrm{C}$ compared to other temperatures.

Photosynthetic recovery was observed after exposure treatment and $48 \mathrm{~h}$ post-cultivation under low white light (Fig. $4 \mathrm{~d}-\mathrm{f}$ ). Recovery was highest in germlings of A. esculenta $(78-112 \%)$ and L. digitata $(73-100 \%)$ cultivated at $7{ }^{\circ} \mathrm{C}$ and $13{ }^{\circ} \mathrm{C}$ regardless of pre-exposure light treatment (Fig. $4 \mathrm{~d}$, e). At the same cultivation temperatures, $S$. latissima germlings recovered only $44-66 \%$ after exposure to $\mathrm{P}$ and $\mathrm{PA}$, and $22-26 \%$ after $\mathrm{PAB}$ pre-exposure (Fig. 4f). At $2{ }^{\circ} \mathrm{C}$ cultivation temperature, A. esculenta recovered $57-59 \%$ in P- and PA-pre-exposed zoospores compared to only $30 \%$ in PAB-pre-exposed zoospores; lower recovery was observed in L. digitata at $38-46 \%$ and $10 \%$ and in S. latissima at $15-18 \%$ and $6 \%$, respectively. At $19{ }^{\circ} \mathrm{C}$, minimal recovery was observed in all species regardless of the pre-exposure light treatment ranging from $8-14 \%$ in A. esculenta and $2-5 \%$ in L. digitata to non-detectable in $S$. latissima. Analysis of variance (2-way ANOVA, $P<0.05$ ) showed a significant effect of the main factors (temperature and radiation) on the $F_{\mathrm{v}} / F_{\mathrm{m}}$ after exposure and recovery in all species investigated and their interaction in $A$. esculenta and L. digitata (Table 3). The Posthoc Duncan's multiple range test (DMRT, $P=0.05$ ) showed a general species-specific sensitivity to experimental radiation and temperature treatments, $S l>L d>A e$; while the capacity to recover PSII function was highest in $A e=L d>S l$. The cumulative negative effect of different light spectra on $F_{\mathrm{v}} / F_{\mathrm{m}}$ among the three kelp species was highest in $\mathrm{PAB}>\mathrm{PA}>\mathrm{P}$; while the effect of radiation treatment on photosynthetic recovery was still evident and measured lowest $F_{\mathrm{v}} / F_{\mathrm{m}}$ in $\mathrm{PAB}<\mathrm{PA}=\mathrm{P}$ after $48 \mathrm{~h}$ under low white light. The effect of temperature on PSII function, after $8 \mathrm{~h}$ exposure to different radiation treatments among the three species, measured lowest $F_{\mathrm{v}} / F_{\mathrm{m}}$ at $2{ }^{\circ} \mathrm{C}<7{ }^{\circ} \mathrm{C}=19{ }^{\circ} \mathrm{C}<13{ }^{\circ} \mathrm{C}$. Continued cultivation under high temperature had a negative impact on the recovery process where $F_{\mathrm{v}} / F_{\mathrm{m}}$ after $48 \mathrm{~h}$ was lowest at $19{ }^{\circ} \mathrm{C}<2{ }^{\circ} \mathrm{C}<$ $7{ }^{\circ} \mathrm{C}<13{ }^{\circ} \mathrm{C}$.

The capacity for non-photochemical quenching (NPQ) was generally highest in L. digitata and lowest in S. latissima (Fig. 5). NPQ in A. esculenta increased with temperature and relative to the total fluence of P, PA and PAB (Fig. 5a). Conversely, NPQ in $L$. digitata was not significantly different between samples exposed to $8 \mathrm{~h}$ of different treatment combination (light $\times$ temperature) and to that of $8 \mathrm{~h}$ control at $19{ }^{\circ} \mathrm{C}$ (Fig. 5b). Available data in $S$. latissima after $4 \mathrm{~h}$ cultivation in low white light and after $8 \mathrm{~h}$ exposure treatment showed limited capacity for nonphotochemical quenching (Fig. 5c). After $48 \mathrm{~h}$ post-cultivation in low white light, NPQ in germlings of A. esculenta and L. digitata pre-exposed to higher PAR and UVR decreased in samples grown at $2{ }^{\circ} \mathrm{C}, 7{ }^{\circ} \mathrm{C}$ and $13{ }^{\circ} \mathrm{C}$ but not in $19{ }^{\circ} \mathrm{C}$ (Fig. 5d, e); while the capacity for NPQ increased in control samples. Generally, the 
Table 2 Mean absolute values $\left( \pm \mathrm{SD}\right.$ ) of spore photosynthetic efficiency (optimum quantum yield, $F_{\mathrm{v}} / F_{\mathrm{m}}$ ) after 8 h exposure treatment to photosynthetically active radiation $(\mathrm{PAR}=\mathrm{P})$; PAR + UV-A radiation $(\mathrm{PA})$; PAR + UV-A + UV-B radiation $(\mathrm{PAB})$ and after $48 \mathrm{~h}$ post-cultivation for photosynthetic recovery under different temperature regime

\begin{tabular}{|c|c|c|c|c|c|c|c|c|}
\hline \multirow[b]{3}{*}{ Species } & \multirow[b]{3}{*}{$T /{ }^{\circ} \mathrm{C}$} & \multicolumn{7}{|c|}{ Optimum quantum yield $\left(F_{\mathrm{v}} / F_{\mathrm{m}}\right)$} \\
\hline & & \multirow[b]{2}{*}{ Control $\left(t_{0}\right)$} & \multicolumn{3}{|l|}{ After exposure } & \multicolumn{3}{|l|}{ After recovery } \\
\hline & & & $\mathrm{P}$ & PA & PAB & $\mathrm{P}$ & PA & PAB \\
\hline \multirow[t]{5}{*}{ A. esculenta } & & $0.421 \pm 0.054$ & & & & & & \\
\hline & 2 & & $0.026 \pm 0.006$ & $0.019 \pm 0.003$ & $0.013 \pm 0.006$ & $0.281 \pm 0.041$ & $0.271 \pm 0.049$ & $0.142 \pm 0.034$ \\
\hline & 7 & & $0.053 \pm 0.008$ & $0.028 \pm 0.004$ & $0.022 \pm 0.010$ & $0.398 \pm 0.032$ & $0.434 \pm 0.020$ & $0.370 \pm 0.029$ \\
\hline & 13 & & $0.093 \pm 0.013$ & $0.045 \pm 0.009$ & $0.038 \pm 0.010$ & $0.451 \pm 0.050$ & $0.533 \pm 0.030$ & $0.457 \pm 0.009$ \\
\hline & 19 & & $0.116 \pm 0.010$ & $0.045 \pm 0.007$ & $0.025 \pm 0.009$ & $0.064 \pm 0.019$ & $0.042 \pm 0.014$ & $0.037 \pm 0.019$ \\
\hline \multirow[t]{5}{*}{ L. digitata } & & $0.442 \pm 0.056$ & & & & & & \\
\hline & 2 & & $0.030 \pm 0.008$ & $0.022 \pm 0.005$ & $0.017 \pm 0.009$ & $0.211 \pm 0.038$ & $0.178 \pm 0.060$ & $0.046 \pm 0.016$ \\
\hline & 7 & & $0.062 \pm 0.010$ & $0.028 \pm 0.006$ & $0.027 \pm 0.004$ & $0.445 \pm 0.074$ & $0.438 \pm 0.054$ & $0.339 \pm 0.066$ \\
\hline & 13 & & $0.071 \pm 0.010$ & $0.040 \pm 0.006$ & $0.029 \pm 0.003$ & $0.453 \pm 0.062$ & $0.461 \pm 0.060$ & $0.351 \pm 0.096$ \\
\hline & 19 & & $0.055 \pm 0.008$ & $0.022 \pm 0.006$ & $0.017 \pm 0.010$ & $0.021 \pm 0.017$ & $0.008 \pm 0.011$ & $0.006 \pm 0.009$ \\
\hline \multirow[t]{5}{*}{ S. latissima } & & $0.450 \pm 0.015$ & & & & & & \\
\hline & 2 & & $0.026 \pm 0.006$ & $0.025 \pm 0.010$ & $0.011 \pm 0.004$ & $0.076 \pm 0.056$ & $0.060 \pm 0.053$ & $0.024 \pm 0.011$ \\
\hline & 7 & & $0.040 \pm 0.012$ & $0.028 \pm 0.008$ & $0.021 \pm 0.007$ & $0.252 \pm 0.105$ & $0.182 \pm 0.140$ & $0.108 \pm 0.109$ \\
\hline & 13 & & $0.059 \pm 0.005$ & $0.027 \pm 0.003$ & $0.027 \pm 0.004$ & $0.269 \pm 0.130$ & $0.254 \pm 0.151$ & $0.091 \pm 0.086$ \\
\hline & 19 & & $0.044 \pm 0.018$ & $0.021 \pm 0.003$ & $0.013 \pm 0.007$ & $0.000 \pm 0.000$ & $0.000 \pm 0.000$ & $0.000 \pm 0.000$ \\
\hline
\end{tabular}

Photon flux density is $22 \mu \mathrm{mol}$ photons $\mathrm{m}^{-2} \mathrm{~s}^{-1}\left(\sim 4.73 \mathrm{~W} \mathrm{~m}^{-2}\right)$. Photosynthetic recovery was initiated in dim white light of $10 \mu \mathrm{mol}$ photons $\mathrm{m}^{-2} \mathrm{~s}^{-1}$ after treatment. Control at time zero $\left(t_{0}\right)$ was measured after spore release.

Table 3 Analysis of variance (repeated measure, RMANOVA, and two-way ANOVA) and significance values for the main effects and interactions of independent variables on photosynthetic efficiency in spores of Alaria esculenta, Laminaria digitata and Saccharina latissima (* significant; ns, not significant)

\begin{tabular}{|c|c|c|c|c|c|}
\hline Experiment/variable & Source of variation & $\mathrm{SS}(\mathrm{W})$ & $\mathrm{df}$ & $F$ value & $P$ value \\
\hline $\begin{array}{l}\text { Temperature } \\
F_{\mathrm{v}} / F_{\mathrm{m}}\end{array}$ & $\begin{array}{l}\text { Species (A) } \\
\text { Temperature (B) } \\
\mathrm{A} \times \mathrm{B}\end{array}$ & $\begin{array}{l}0.830 \\
2.797 \\
0.160\end{array}$ & $\begin{array}{l}2 \\
3 \\
6\end{array}$ & $\begin{array}{r}68.412 \\
153.693 \\
4.402\end{array}$ & $\begin{array}{r}<0.001 * \\
<0.001 * \\
\\
0.002 *\end{array}$ \\
\hline $\begin{array}{l}\text { Temperature } \times \text { radiation } \\
F_{\mathrm{v}} / F_{\mathrm{m}}(\text { after treatment })\end{array}$ & Species & 0.032 & 2 & 3.851 & $0.023 *$ \\
\hline Alaria esculenta & $\begin{array}{l}\text { Temperature (A) } \\
\text { Radiation }(\mathrm{B}) \\
\mathrm{A} \times \mathrm{B}\end{array}$ & $\begin{array}{l}0.019 \\
0.025 \\
0.010\end{array}$ & $\begin{array}{l}3 \\
2 \\
6\end{array}$ & $\begin{array}{r}90.968 \\
181.510 \\
23.613\end{array}$ & $\begin{array}{l}<0.001 * \\
<0.001 * \\
<0.001 *\end{array}$ \\
\hline Laminaria digitata & $\begin{array}{l}\text { Temperature }(\mathrm{A}) \\
\text { Radiation }(\mathrm{B}) \\
\mathrm{A} \times \mathrm{B}\end{array}$ & $\begin{array}{l}0.005 \\
0.012 \\
0.002\end{array}$ & $\begin{array}{l}3 \\
2 \\
6\end{array}$ & $\begin{array}{r}27.936 \\
107.596 \\
5.345\end{array}$ & $\begin{array}{l}<0.001 * \\
<0.001 * \\
<0.001 *\end{array}$ \\
\hline Saccharina latissima & $\begin{array}{l}\text { Temperature (A) } \\
\text { Radiation }(\mathrm{B}) \\
\mathrm{A} \times \mathrm{B}\end{array}$ & $\begin{array}{l}0.013 \\
0.033 \\
0.006\end{array}$ & $\begin{array}{l}3 \\
2 \\
6\end{array}$ & $\begin{array}{r}7.371 \\
27.382 \\
1.565\end{array}$ & $\begin{array}{r}0.001 * \\
<0.001 * \\
0.201^{\mathrm{ns}}\end{array}$ \\
\hline$F_{\mathrm{v}} / F_{\mathrm{m}}($ after recovery $)$ & Species (A) & 1.274 & 1 & 13.668 & $<0.001 *$ \\
\hline Alaria esculenta & $\begin{array}{l}\text { Temperature }(\mathrm{A}) \\
\text { Radiation }(\mathrm{B}) \\
\mathrm{A} \times \mathrm{B}\end{array}$ & $\begin{array}{l}2.059 \\
0.053 \\
0.051\end{array}$ & $\begin{array}{l}3 \\
2 \\
6\end{array}$ & $\begin{array}{r}555.908 \\
21.395 \\
6.843\end{array}$ & $\begin{array}{l}<0.001 * \\
<0.001 * \\
<0.001 *\end{array}$ \\
\hline Laminaria digitata & $\begin{array}{l}\text { Temperature (A) } \\
\text { Radiation }(\mathrm{B}) \\
\mathrm{A} \times \mathrm{B}\end{array}$ & $\begin{array}{l}3.116 \\
0.162 \\
0.074\end{array}$ & $\begin{array}{l}3 \\
2 \\
6\end{array}$ & $\begin{array}{r}320.887 \\
25.089 \\
3.798\end{array}$ & $\begin{array}{r}<0.001 * \\
<0.001 * \\
\\
0.004 *\end{array}$ \\
\hline Saccharina latissima & $\begin{array}{l}\text { Temperature (A) } \\
\text { Radiation (B) } \\
\mathrm{A} \times \mathrm{B}\end{array}$ & $\begin{array}{l}0.951 \\
0.114 \\
0.058\end{array}$ & $\begin{array}{l}3 \\
2 \\
6\end{array}$ & $\begin{array}{r}27.391 \\
4.936 \\
0.833\end{array}$ & $\begin{array}{r}<0.001 * \\
0.016 * \\
0.556^{\text {ns }}\end{array}$ \\
\hline
\end{tabular}

Radiation treatments consist of photosynthetically active radiation (PAR $=$ P), PAR + UV-A (PA) and PAR + UV-A + UV-B (PAB). SS (W), within group variation; df $(=n-1)$, degree of freedom; $F$, ratio of the model mean square to the error mean square which refers to the data distribution; $P$ value, level of significance of the statistical test. 

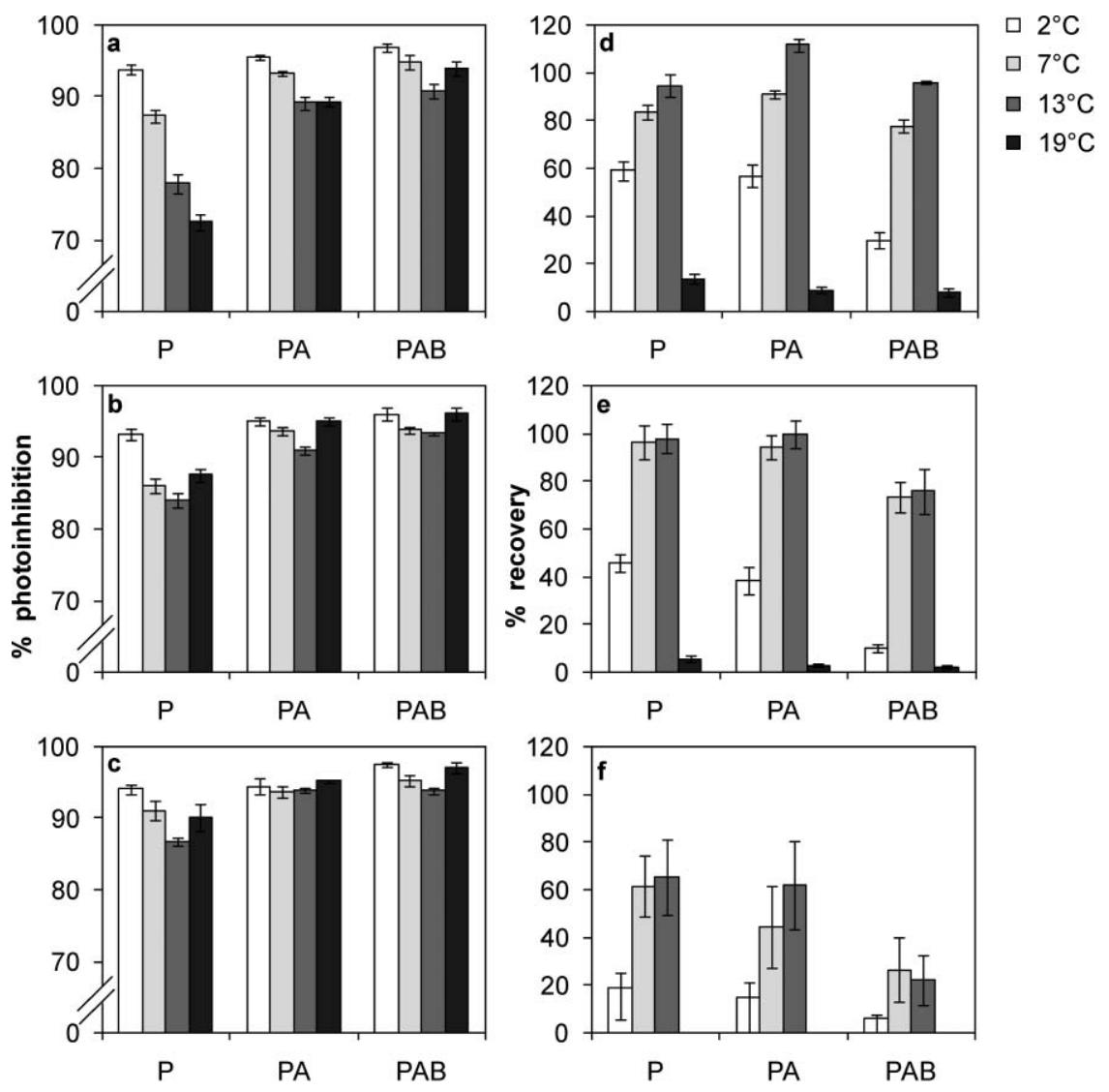

Radiation

Fig. 4 Mean photoinhibition of photosynthesis after $8 \mathrm{~h}$ exposure to photosynthetically active radiation (PAR $=$ P), PAR + UV-A (PA) and PAR + UV-A + UV-B (PAB) at different temperatures in (a) Alaria esculenta, (b) Laminaria digitata and (c) Saccharina latissima expressed as percentage of control $\left(F_{\mathrm{v}} / F_{\mathrm{m}}\right.$ after release). Corresponding photosynthetic recovery (d, e and f, respectively) after $48 \mathrm{~h}$ post-culture in dim white light $(10 \mu \mathrm{mol}$ photons $\mathrm{m}^{-2} \mathrm{~s}^{-1}$ ) expressed as percent of control (maximum $F_{\mathrm{v}} / F_{\mathrm{m}}$ at $13{ }^{\circ} \mathrm{C}$ ). Vertical bars are standard errors $(\mathrm{SE}, n=5$ ). No photosynthetic recovery was observed under $19^{\circ} \mathrm{C}$ in S. latissima. Corresponding analysis of variance, ANOVA is shown in Table 3.

capacity for NPQ in S. latissima also increased after 48 h postcultivation; PSII function and NPQ was not detectable at $19{ }^{\circ} \mathrm{C}$ cultivation temperature (Fig. 5f).

\section{Discussion}

Photosynthetic performance of zoospores from Arctic kelp population was promoted at temperatures higher than in the natural environment. Moreover, photoinhibition of photosynthesis was higher at lower temperature $\left(2{ }^{\circ} \mathrm{C}\right)$ regardless of the spectral irradiance composition compared to temperature near ambient in the natural environment $\left(7^{\circ} \mathrm{C}\right)$ and maximum spring-time cold temperate seawater temperature $\left(13{ }^{\circ} \mathrm{C}\right)$. Zoospores were able to sustain $50 \%$ of PSII function at $19^{\circ} \mathrm{C}$ up to $24 \mathrm{~h}$ in Alaria esculenta and only $4 \mathrm{~h}$ in Laminaria digitata and Saccharina latissima. The capacity for photosynthetic recovery was highest at $13{ }^{\circ} \mathrm{C}$ in $A$. esculenta; comparable at $7{ }^{\circ} \mathrm{C}$ and $13{ }^{\circ} \mathrm{C}$ in L. digitata and also in $S$. latissima but at a lower range. Photosynthetic recovery was further depressed at extreme low and high temperatures in zoospores previously exposed to the whole UVR spectrum; zoospores of $S$. latissima were most susceptible and $A$. esculenta were more tolerant to the combined UV-B and temperature stress. Generally, the higher capacity for non-photochemical quenching
(NPQ) in A. esculenta and L. digitata helped regulate and protect photosynthesis under light and temperature stress compared to S. latissima.

Under a warmer climate scenario in the Arctic, with a realistic temperature increment, the photosynthetic performance (this study) and germination capacity ${ }^{33}$ under UVR of some kelp species with wide geographic distribution may not be as severely affected as theoretically projected. Light and temperature may, however, affect the Arctic endemic Laminaria solidungula; its zoospores and gametophytes are more susceptible to high radiation and high temperature stress than the investigated species $^{36,37}$ and sporophytes grow rapidily in winter under thick ice cover. ${ }^{38}$ Moreover, the reproduction of the "rare and localized endemic" Arctic Saccorhiza dermatodea ${ }^{39}$ can also be compromised as maturation of gametangia requires 6 weeks of exposure to $0^{\circ} \mathrm{C} .4^{40,41}$

Thermal and photoacclimation of photosynthesis in the sporophytes of panoceanic ${ }^{39}$ Saccharina latissima (previously Laminaria saccharina) had been previously reported..$^{23,42-44}$ The increase in photosynthetic efficiency $(\alpha)$ with increasing temperature in zoospores (this study) was also reported in sporophytes of the same species, associated with the increase in Chl $a$ and functional PSII reaction centers. ${ }^{43,44}$ The increasing $F_{\mathrm{v}} / F_{\mathrm{m}}$ was observed at cultivation temperatures up to $13{ }^{\circ} \mathrm{C}$; a response also consistent 


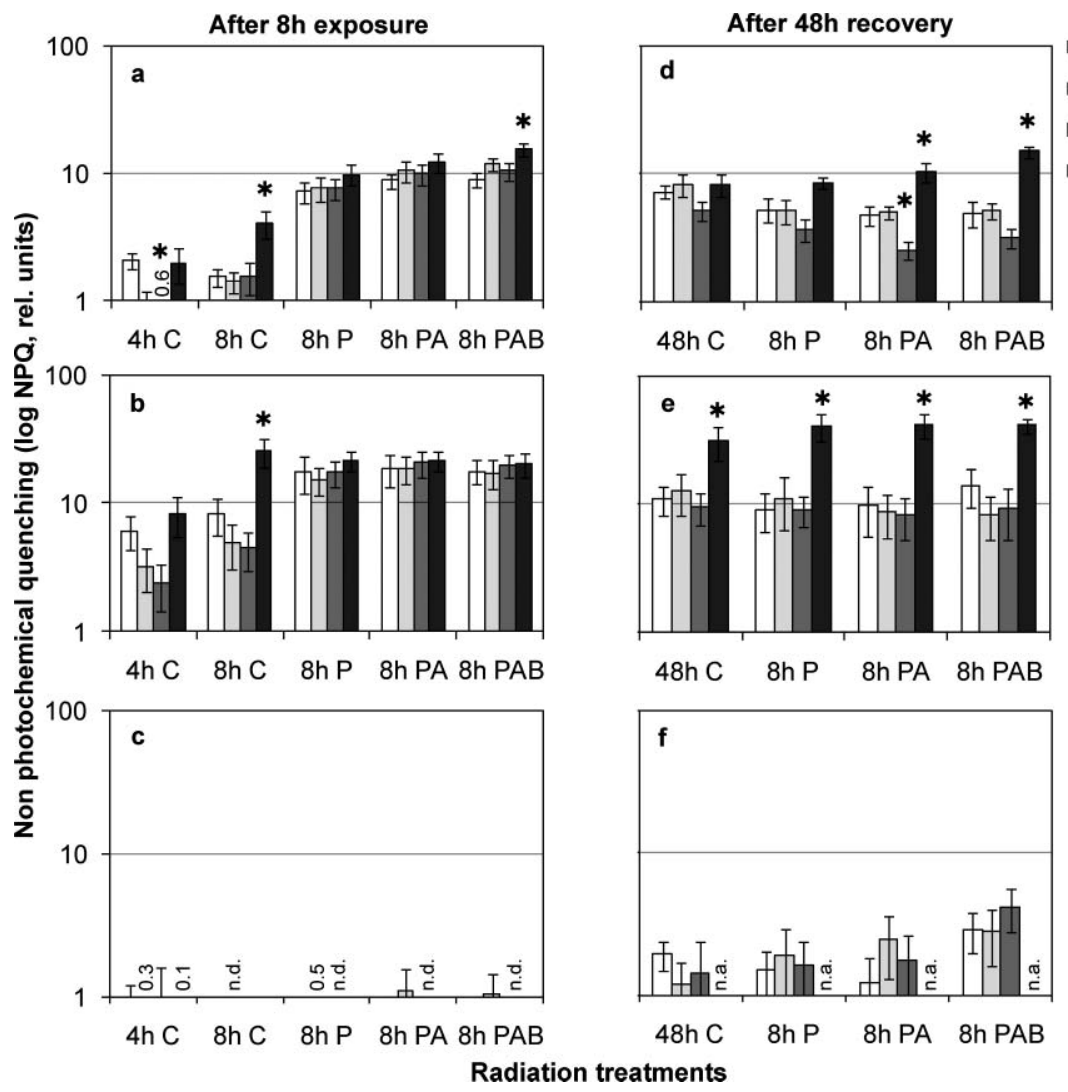

Fig. 5 Non-photochemical quenching (NPQ) as a function of temperature and radiation treatment in zoospores of (a, d) Alaria esculenta, (b, e) Laminaria digitata and (c, f) Saccharina latissima after exposure treatment and post-culture in dim white light $\left(10 \mu \mathrm{mol}\right.$ photons $\left.\mathrm{m}^{-2} \mathrm{~s}^{-1}\right)$. Radiation treatments consist of photosynthetically active radiation $(\mathrm{PAR}=\mathrm{P})$, PAR + UV-A $(\mathrm{PA})$ and PAR + UV-A + UV-B (PAB) at different culture temperatures. Control (C) was measured after 4, 8 and $48 \mathrm{~h}$ incubation in respective temperature chambers under dim white light. Vertical bars are standard errors (SE, $n=5$ ). No available data (n.d.) for S. latissima at $8 \mathrm{~h} \mathrm{C}$, and under 2,13 and $19^{\circ} \mathrm{C}$ after exposure treatments. PSII function and NPQ were non-detectable (n.a.) after $48 \mathrm{~h}$ in $19^{\circ} \mathrm{C}$ - cultivated $S$. latissima. Analysis of variance (ANOVA, $P<0.05$ ) and Post-hoc test (DMRT, $P=0.05$ ) showed with * significantly vary from the group.

with previous data for $S$. latissima sporophytes measuring higher maximum photon yield $\left(\mathrm{O}_{2}\right.$ evolved per absorbed photon, $\Phi_{\max }$, an indicator of $\left.F_{\mathrm{v}} / F_{\mathrm{m}}\right)$ when grown at high temperature as opposed to low temperature. ${ }^{43}$

The $F_{\mathrm{v}} / F_{\mathrm{m}}$ measured after $8 \mathrm{~h}$ at low temperature $\left(\mathrm{LT} ; 2^{\circ} \mathrm{C}\right.$ ) and high light (HL; treatment, $22 \mu \mathrm{mol}$ photons $\mathrm{m}^{-2} \mathrm{~s}^{-1}$ ) was lower compared to the same temperature at low light (LL; control, $10 \mu \mathrm{mol}$ photons $\left.\mathrm{m}^{-2} \mathrm{~s}^{-1}\right)$ in A. esculenta $(\mathrm{LT} / \mathrm{HL}=0.026 ; \mathrm{LT} / \mathrm{LL}=0.392)$ and $L$. digitata $(\mathrm{LT} / \mathrm{HL}=0.030 ; \mathrm{LT} / \mathrm{LL}=0.225)$. The reductions in $F_{\mathrm{v}} / F_{\mathrm{m}}$ in zoospores grown at $\mathrm{LT} / \mathrm{HL}$ was due to an increase in energy dissipation away from PSII, i.e. non-photochemical quenching; an inverse response of low $F_{\mathrm{v}} / F_{\mathrm{m}}$ and high NPQ was observed in this study (Fig. 5a, b), suggesting that algae grown under low-temperature/high-light conditions can be exposed to potentially damaging excess light energy. ${ }^{44}$ Low temperature can inhibit electron transport through alterations in the biophysical properties of thylakoid lipids increasing membrane viscosity and by strongly decreasing the rates of the enzymatic reactions involved in $\mathrm{C}, \mathrm{N}$ and $\mathrm{S}$ reduction than they inhibit photophysical and photochemical processes involved in light absorption, energy transfer and transformation. ${ }^{45,46}$

Conversely, the short-term response to high temperatures and "higher" irradiance of PAR (relative to control) appear to enhance the protective mechanism where percent photoinhibition was lower at higher temperature (Fig. $4 \mathrm{a}-\mathrm{c}$ ), but disrupt repair processes (Fig. 4d-f). The low photoinhibition of zoospores studied at temperatures higher than ambient was unexpected. Photoinhibition is usually enhanced at high temperatures because PSII, and the thylakoids in general, are temperature sensitive. ${ }^{23}$ The same response was also reported on the photosynthetic performance of S. latissima sporophytes unaffected by higher temperature up to $22^{\circ} \mathrm{C} .{ }^{47}$ The short exposure period ( $8 \mathrm{~h}$ in this study) might account for lack of high-temperature enhancement of photoinhibition. The decline of photosynthesis at $19{ }^{\circ} \mathrm{C}$ was, however, observed after $48 \mathrm{~h}$ post-cultivation. Moderate heat stress can stimulate dark reduction of plastoquinone and cyclic electron flow in the light, increase thylakoid leakiness, deactivate rubisco and increase $\mathrm{H}_{2} \mathrm{O}_{2}$ production. Surprisingly, moderate heat stress is reported to result in little or no damage to PSII even though photosynthetic rate is reduced to near zero. ${ }^{48}$ Altering thylakoid lipid composition enables plants to withstand moderately high temperature. The deactivation of rubisco at moderately high temperature is thought to be a parallel deleterious effect or a regulatory response to limit damage to thylakoid reactions. ${ }^{48}$ On the other hand, the cellular sites and rates of reactive oxygen species (ROS) production during temperature stress play a central role in stress perception and protection. ${ }^{49}$ 
Photosynthetic efficiency of spores after exposure treatments decreased to fluorescence ratios below 0.1 (Table 2), which may not be reliable anymore. Despite the methodological limitation, the measured $F_{\mathrm{v}} / F_{\mathrm{m}}$ values were coherent among replicates and treatments (radiation $\times$ exposure time) so that an additional UVeffect can be assumed.

Fluorescence data and mean $F_{\mathrm{v}} / F_{\mathrm{m}}$ measured in this study was comparable to that of a previous study on zoospores of the same kelp species exposed to similar experimental irradiance of $\mathrm{P}$, $\mathrm{PA}$ and PAB at $7{ }^{\circ} \mathrm{C} .{ }^{22}$ Moreover, photosynthetic performance at $13{ }^{\circ} \mathrm{C}$ in zoospores of Arctic L. digitata and S. latissima measured $F_{\mathrm{v}} / F_{\mathrm{m}}$, comparable to that of the cold-temperate population of the same species cultivated at $10{ }^{\circ} \mathrm{C}$ after exposure to corresponding irradiance. ${ }^{50}$ Recovery of photoinhibition was also comparable between populations of the two species except for the two-fold better recovery process in PAB-exposed Arctic $L$. digitata zoospores at $13{ }^{\circ} \mathrm{C}$ (this study) compared to $\mathrm{PAB}$-exposed Helgolandic L. digitata at $10{ }^{\circ} \mathrm{C} .{ }^{50}$ Zoospore germination was also higher in the Arctic population of L. digitata compared to Helgolandic population exposed to the whole light spectrum at all temperature except at $18{ }^{\circ} \mathrm{C} .{ }^{33}$ An opposite trend was observed in S. latissima where the Helgolandic population was more tolerant to the combined temperature and light stress compared to the Arctic population. ${ }^{33}$

Population-specific response in S. latissima sporophytes was also observed between the population at the southern end of the species' geographic range in the North Atlantic and the population from the higher latitude. The southern population was able to survive higher temperature compared to the northern population ${ }^{51}$, indicating natural selection in an unfavorable environment may result in genotypic variation. Based on genetic and fossil evidence, the laminarians are evolving rapidly., ${ }^{8,52}$ It is likely that Laminariales together with Desmarestiales and Fucales evolved at a time when there were no significant low-temperature $\left(<5{ }^{\circ} \mathrm{C}\right)$ surface seawaters ${ }^{53,54}$ until the Antarctic cooled some $15 \mathrm{Ma}$ ago. Despite this, many of the present dominant macroalgae in cold seas are large brown seaweeds, and many laminarians cannot reproduce at temperatures above $18-25{ }^{\circ} \mathrm{C} .{ }^{55}$ Recent molecular evidence ${ }^{56}$ supports the view that a Laminaria ancestor from the North Pacific entered the Arctic and North Atlantic during the latest Pliocene or Pleistocene with rapid spread and speciation in the Atlantic. ${ }^{39}$ Aside from traditional evolutionary theory that natural selection occurs among individuals produced sexually, somatic mutation, mitotic recombination, ploidy changes and rapid changes in genotype have all been documented in clonal lineages of macroalgae. ${ }^{57}$

Under a combined action of light and heat stress, strong light induces photodamage of PSII due to the direct action of light on the oxygen-evolving complex while production of ROS, such as $\mathrm{H}_{2} \mathrm{O}_{2}$, significantly increases with the rise in temperature. ${ }^{58}$ Stress-induced accumulation of ROS leads to inhibition of the recovery of the PSII by suppressing the de novo synthesis of photosynthetic proteins. The synergistic effect of light and heat stress on photoinhibition is manifested even at relatively "low" PAR and severely under the whole light spectrum after $48 \mathrm{~h}$ at $19^{\circ} \mathrm{C}$. At moderate heat stress, the loss of photosynthetic activity is partly due to the inhibition of the acceptor side of the PSII and lower rate of electron transport in chloroplast. The PAR treatment we used at $22 \mu \mathrm{mol}$ photons $\mathrm{m}^{-2} \mathrm{~s}^{-1}$ is, however, already saturating for the zoospores. At severe heat stress, the inactivation of PSII gradually becomes irreversible, predominantly at the expense of the charge separation in reaction centers of the PSII, dissociation of some specific proteins in the core complex, significant reduction of electron transport rates due to structural rearrangements in thylakoid membranes and disturbances in the system responsible for $\mathrm{CO}_{2}$ assimilation. ${ }^{58}$

A relatively higher input of short wave irradiation to PAR (high UVR: PAR ratio) was applied in the laboratory. Despite this experimental limitation in simulating the PAR/UV ratios as in the field (which would require a very difficult technical setup), the UV irradiances comparable to those encountered in the field had a negative impact on the photobiology and photochemistry of zoospores of different kelp species. UVR can, however, not be regarded as an "excessive energy input" in a proper sense. Its maximal irradiance is much smaller than of PAR and the UV wavebands do not contribute a significant energy supply for photosynthetic chemistry. Consequently, photoinhibition of photosynthesis was significantly lower under UV-only treatment compared to PAR + UV-A (PA) and PAR + UV-A + UV-B (PAB) treatment among tropical macrophytes exposed to ambient solar radiation. ${ }^{59}$ Initiation of photosynthetic recovery processes in some eulittoral macroalgae and seagrass in the presence of low irradiance of short UV-wavelengths was observed. This phenomenon suggests a "positive" UV-B effect which remains controversial and needs further study. This mechanism presents some ecophysiological advantage compared to species which initiate the photosynthetic recovery process during low light or in the absence of UV. ${ }^{59}$ Likewise, kinetic study on the PSII damage and repair in the diatom Thalassiosira pseudonana showed that the species was able to acclimate to UVR and photosynthetic recovery was already initiated under UVR exposure. ${ }^{28}$

Generally, UV has a direct adverse effect on photosynthesis. The UV-B inhibition spectrum corresponds much more with the spectral absorption by DNA and proteins rather than with photosynthetic pigments. ${ }^{60}$ UVR can additionally depress photosynthetic performance by possible damage to the oxidizing site and reaction center of PSII. ${ }^{61,62}$ UV-A damage PSII by decreasing electron flow from the reaction centers to plastoquinone ${ }^{61}$ affecting electron transport both at the water oxidizing complex and the binding site of the $\mathrm{Q}_{\text {в }}$ quinone electron acceptor ${ }^{62}$ while $\mathrm{UV}-\mathrm{B}$ is responsible for the degradation of parts of the D1/D2 heterodimer, the major structural complex within PSII. ${ }^{63}$

Consequently, numerous studies have shown that recovery from photoinhibition is delayed after exposure to additional UV-B irradiation. ${ }^{22,64}$ Kelp zoospores have a transitory planktonic phase. Considering their small size and the viscosity of water, ${ }^{65}$ they may be able to vertically swim at a speed of $120 \mu \mathrm{m} \mathrm{s}^{-1}$ covering a distance of $1 \mathrm{~m}$ in $2 \mathrm{~h}^{22}$ Therefore, zoospores released from a 2-4 m tall kelp sporophyte should be able to touch-down and settle into a low-light environment under algal canopies within $8 \mathrm{~h}$. Propagules are also released as a plume of spore cloud. Zoospores with phlorotannin-containing physodes could effectively buffer each other acting as a UV-biofilter. ${ }^{66}$ Even with extended exposure of Arctic A. esculenta and L. digitata zoospores to $24 \mathrm{~h}$ of polar day ambient solar radiation at different depths in Kongsfjorden, zoospores were to some extent able to resume their physiological functions and germinate under low PAR in the laboratory. ${ }^{67}$ 
The ameliorating effects of increased temperature under UVR in Arctic kelp zoospores was observed on the repair of PSII function, showing significantly higher photosynthetic recovery between $7-13{ }^{\circ} \mathrm{C}$ compared to $2{ }^{\circ} \mathrm{C}$ temperature (Fig. $4 \mathrm{~d}-\mathrm{f}$ ). This finding is consistent with the ameliorating effect of moderate temperature increase on the net biological UVR effect reported on photosynthesis and growth of different phytoplankton species ${ }^{25-28}$ and in the relatively higher germination capacity of UVR-exposed Alaria marginata zoospores at $15{ }^{\circ} \mathrm{C}$ compared to $10{ }^{\circ} \mathrm{C} .{ }^{32}$

Non-photochemical dissipation of excess light energy is a shortterm response, first-line defence and one of the most efficient protective mechanisms against photostress. ${ }^{68,69}$ Consequently, during 8 and 48 h measurements, we observed no consistent relationship between combined light and thermal stress and changes in light energy dissipation via a non-photochemical pathway; a similar response was observed in high- and low-light acclimated dinoflagellates subjected to thermal stress. ${ }^{70}$ Aside from inducing NPQ, other protective mechanisms of the photosynthetic apparatus operating against photooxidation includes: (1) dissipation of light energy in the light-harvesting complex of PSII and low efficiency of its transfer to the core-complex of the PSII, (2) dissipation of excess light energy via the proton gradient on the thylakoid membrane, (3) quenching of free radicals in the course of oxidative stress, (4) repair and resynthesis of targets (e.g. D1 protein) photodamaged by oxidative stress, (5) changes in the lipid composition of the thylakoid membrane, (6) cyclic electron transport via PSII and PSI, (7) aggregation of thylakoid proteins and (8) photorespiration among others. ${ }^{58}$

The temperature optima for photosynthesis in different kelp species' zoospores were observed between $7{ }^{\circ} \mathrm{C}$ and $13{ }^{\circ} \mathrm{C}$ higher than that of the reported optimum temperature for germination between $2{ }^{\circ} \mathrm{C}$ and $12{ }^{\circ} \mathrm{C} .{ }^{33}$ The same discrepancy between the thermal relationships of growth and photosynthesis in $S$. latissima sporophytes was observed and discussed by Davison. ${ }^{23,42}$ The thermal stability of PSII effectively determines the upper temperature tolerance of photosynthesis. Above the temperature optima, the lability of PSII is dependent on the period of heat stress. After $48 \mathrm{~h}$, the germlings were capable of photosynthetic recovery but eventually succumbed to severe temperature stress after 6 days when mortality rate was $100 \% 0^{33}$ even in the relatively heat-stress tolerant $A$. esculenta.

\section{Conclusion}

In summary, short-term response to increase temperature was non-lethal for Arctic kelp zoospores and can be reversible while a moderate temperature increase had an ameliorating effect on the overall biological effect of UVR. Synergistic effects of environmental stress factors showed different short- and longterm effects and the physiological response was species-specific. Beyond a tolerance breadth, certain algae, e.g. Arctic S. latissima ecotype (and also the Arctic endemic L. solidungula) may be more susceptible to the negative impact of global climate changerelated stress factors. The investigated kelp species may be able to survive the projected $6{ }^{\circ} \mathrm{C}$ temperature increase in their Arctic habitat but the southernmost distribution range of the species may shift to higher latitude, although natural selection in the southern population exposed to climate change-related stress factors favoring new genotypes is not improbable. The ability for complex metabolic regulation to optimize photosynthesis over the wide range of temperatures and irradiance levels encountered in nature is therefore necessary for the biogeographic distribution extent and limit of a species.

\section{Acknowledgements}

This study was financed by Alfred Wegener Institute for Polar and Marine Research (AWI) and performed at the International Arctic Environmental Research and Monitoring Facility at $\mathrm{Ny}$ Ålesund, Svalbard. The author thanks the AWI-SCUBA diving team and the group leader M. Schwanitz for sample collection, and Prof. C. Wiencke for the research opportunity and for reading the manuscript.

\section{References}

1 A. Arguez, A. M. Waple and A. M. Sanchez-Lugo, State of the climate in 2006- executive summary, Bull. Am. Meteorol. Soc., 2007, 88, 929932.

2 IPCC, Climate Change 2007: The Physical Science Basis. Contribution of Working Group I to the Fourth Assessment Report of the Intergovernmental Panel on Climate Change, Cambridge University Press, Cambridge, UK, 2007.

3 F. Joos and R. Spahni, Rates of change in natural and anthropogenic radiative forcing over the past 20,000 years, Proc. Natl. Acad. Sci. U. S. A., 2008, 105, 1425-1430.

4 M. C. Serreze and J. A. Francis, The Arctic amplification debate, Clim. Change, 2006, 76, 241-264.

5 R. G. Graversen, T. Mauritsen, M. Tjernström, E. Källén and G. Svensson, Vertical structure of recent Arctic warming, Nature, 2008, 541, 53-56.

6 D. K. Perovich, B. Light, H. Eicken, K. F. Jones, K. Runciman and S. V. Nghiem, Increasing solar heating of the Arctic Ocean and adjacent seas, 1979-2005: attribution and role in the ice-albedo feedback, Geophys. Res. Lett., 2007, 34, L19505, DOI: 10.1029/2007GL031480.

7 A. M. Breeman, Expected effects of changing seawater temperatures on the geographic distribution of seaweed species, in Expected Effects of Climatic Change on Marine Coastal Ecosystems, ed. J. J. Beukema, W. J. Wolff and J. W. M. Brouns, 1990, Kluwer Academic Publishers, Netherlands, pp. 69-76.

8 K. Lüning, in Seaweeds: Their Environment, Biogeography and Ecophysiology, Wiley-Interscience, New York, 1990, 527 pp.

9 I. tom Dieck, Temperature tolerance and survival in darkness of kelp gametophytes (Laminariales, Phaeophyta): ecological and biogeographical implications, Mar. Ecol.: Prog. Ser., 1993, 100, 253-264.

10 C. Wiencke, I. Bartsch, B. Bischoff, A. F. Peters and A. M. Breeman, Temperature requirements and biogeography of antarctic, arctic and amphiequatorial seaweeds, Bot. Mar., 1994, 37, 247-259.

11 D. R. Schiel, J. R. Steinbeck and M. S. Forster, Ten years of induced ocean warming causes comprehensive changes in marine benthic communities, Ecology, 2004, 85, 1833-1839.

12 L. B. Ladah and J. A. Zertuche-González, Survival of microscopic stages of a perennial kelp (Macrocystis pyrifera) from the center and the southern extreme of its range in the Northern Hemisphere after exposure to simulated El Niño stress, Mar. Biol., 2007, 152, 677-686.

13 P. G. Matson and M. S. Edwards, Effects of ocean temperature on the southern range limits of two understory kelps, Pterygophora californica and Eisenia arborea, at multiple life-stages, Mar. Biol., 2007, 151, 19411949.

14 A. M. Breeman and H. Pakker, Temperature ecotypes in seaweeds: adaptive significance and biogeographic implications, Bot. Mar., 1994, 37, 171-180.

15 D. W. Fahey, Twenty Questions and Answers About the Ozone Layer: Scientific Assessment of Ozone Depletion: 2002, World Meteorological Organization, Geneva, 2003.

16 J. J. Jin, K. Semeniuk, G. L. Manney, A. I. Jonsson, S. R. Beagley, J. C. McConnell, G. Dufour, R. Nassar, C. D. Boone, K. A. Walker, P. F. Bernath and C. P. Rinsland, Severe Arctic ozone loss in the winter 2004/2005: observations from ACE-FTS, Geophys. Res. Lett., 2006, 33, L15801, DOI: 10.1029/2006GL026752. 
17 G. Muscari, A. G. di Sarra, R. L. de Zafra, F. Lucci, F. Baordo, F. Angelini and $\mathrm{G}$. Fiocco, Middle atmospheric $\mathrm{O}_{3}, \mathrm{CO}, \mathrm{N}_{2} \mathrm{O}, \mathrm{HNO}_{3}$, and temperature profiles during the warm Arctic winter 2001-2002, J. Geophys. Res. [Atmos.], 2007, 112, D14304, DOI: 10.1029/2006JD7849.

$18 \mathrm{M}$. Tedetti and R. Sempéré, Penetration of ultraviolet radiation in the marine environment. A review, Photochem. Photobiol., 2006, 82, 389397.

19 D. R. Ort, When there is too much light, Plant Physiol., 2001, 125, 29-32.

20 A. Melis, Photosystem-II damage and repair cycle in chloroplasts: what modulates the rate of photodamage in vivo?, Trends Plant Sci., 1999, 4, 130-135.

21 N. Ohnishi, N. S. I. Allakhverdiev, S. Takahashi, S. Higashi, M. Watanabe, Y. Nishiyama and N. Murata, Two-step mechanism of photodamage to photosystem II: step 1 occurs at the oxygen-evolving complex and step 2 occurs at the photochemical reaction center, Biochemistry, 2005, 44, 8494-8499.

22 M. Y. Roleda, D. Hanelt and C. Wiencke, Exposure to ultraviolet radiation delays photosynthetic recovery in Arctic kelp zoospores, Photosynth. Res., 2006, 88, 311-322.

23 L. R. Davidson, Environmental effects on algal photosynthesis: temperature, J. Phycol., 1991, 27, 2-8.

24 D. C. Fork, N. Murata and N. Sato, Effect of growth temperature on the lipid and fatty acid composition, and the dependence on temperature of light-induced redox reactions of cytochrome $f$ and of light energy redistribution in the thermophilic blue-green alga Synechococcus lividus, Plant Physiol., 1979, 63, 524-530.

25 R. Rae and W. F. Vincent, Effects of temperature and UV radiation on microbial food web structure: potential responses to global change, Freshwater Biol., 1998, 40, 1-12.

26 J. C. Roos and W. F. Vincent, Temperature dependence of UV radiation effects on Antarctic cyanobacteria, J. Phycol., 1998, 34, 118-125.

27 S. Doyle, J. E. Saros and C. E. Williamson, Interactive effects of temperature and nutrient limitation on the response of alpine phytoplankton growth to UV radiation, Limnol. Oceanogr., 2005, 50, 1362-1367.

28 C. Sobrino and P. J. Neale, Short-term and long-term effects of temperature on photosynthesis in the diatom. Thalassiosira pseudonana under UVR exposures, J. Phycol., 2007, 43, 426-436.

29 H. Pakker, C. A. C. Beekman and A. M. Breeman, Efficient photoreactivation of UVBR-induced DNA damage in the sublittoral macroalga Rhodymenia pseudopalmata (Rhodophyta), Eur. J. Phycol., 2000, 35, 109-114.

30 H. Pakker, R. S. T. Martins, P. Boelen, A. G. J. Buma, O. Nikaido and A. M. Breeman, Effects of temperature on the photoreactivation of UVB-induced DNA damage in Palmaria palmata (Rhodophyta), J. Phycol., 2000, 36, 334-341.

31 W. H. van de Poll, A. Eggert, A. G. J. Buma and A. M. Breeman, Temperature-dependence of UV radiation effects in Arctic and temperate isolates of three red macrophytes, Eur. J. Phycol., 2002, 37, 59-68.

32 J. R. Hoffman, L. J. Hansen and T. Klinger, Interaction between UV radiation and temperature limit inferences from single-factor experiments, J. Phycol., 2003, 39, 268-272.

33 R. Müller, C. Wiencke and K. Bischof, Interactive effects of UV radiation and temperature on microstages of Laminariales (Phaeophyceae) from the arctic and North Sea, Clim. Res., 2008, 37, 203-213.

34 D. Hanelt, H. Tüg, K. Bischof, C. Groß, H. Lippert, T. Sawall and C. Wiencke, Light regime in an arctic fjord: a study related to stratospheric ozone depletion as a basis for determination of UV effects on algal growth, Mar. Biol., 2001, 138, 649-658.

35 A. D. Jassby and T. Platt, Mathematical formulation of the relationship between photosynthesis and light for phytoplankton, Limnol. Oceanogr., 1976, 21, 540-547.

36 I. tom Dieck, North Pacific and North Atlantic digitate Laminaria species (Phaeophyta): hybridization experiments and temperature responses, Phycologia, 1992, 31, 147-163.

37 C. Wiencke, M. N. Clayton and M. E. A. Schoenwaelder, Sensitivity and acclimation to UV radiation of zoospores from five species of Laminariales from the Arctic, Mar. Biol., 2004, 145, 31-39.

38 A. R. O. Chapman and J. E. Lindley, Seasonal growth of Laminaria solidungula in the Canadian High Arctic in relation to irradiance and dissolved nutrient concentrations, Mar. Biol., 1980, 57, 1-5.

39 W. H. Adey, S. C. Lindstrom, M. H. Hommersand and K. M. Müller, The biogeographic origin of Arctic endemic seaweeds: a thermogeographic view, J. Phycol., 2008, 44, 1384-1394.
40 E. C. Henry, Primitive reproductive characters and a photoperiodic response in Saccorhiza dermatodea (Laminariales, Phaeophyceae), Br. Phycol. J., 1987, 22, 23-31.

41 E. C. Henry, Regulation of reproduction in brown algae by light and temperature, Bot. Mar., 1988, 31, 353-357.

42 I. R. Davison, Adaptation of photosynthesis in Laminaria saccharina (Phaeophyta) to changes in growth temperature, J. Phycol., 1987, 23, 273-283.

43 I. R. Davison, R. M. Greene and E. J. Podolak, Temperature acclimation of respiration and photosynthesis in the brown alga Laminaria saccharina, Mar. Biol., 1991, 110, 449-454.

44 K. M. Machalek, I. R. Davison and P. G. Falkowski, Thermal acclimation and photoacclimation of photosynthesis in the brown alga Laminaria saccharina, Plant Cell Environ., 1996, 19, 10051016.

45 N. P. A. Huner, G. Öquist and F. Sarhan, Energy balance and acclimation to light and cold, Trends Plant Sci., 1998, 3, 224-230.

46 I. Ensminger, F. Busch and N. P. A. Huner, Photostasis and cold acclimation: sensing low temperature through photosynthesis, Physiol. Plant., 2006, 126, 28-44.

47 J. Bruhn and V. A. Gerard, Photoinhibition and recovery of the kelp Laminaria saccharina at optimal and superoptimal temperatures, Mar. Biol., 1996, 125, 639-648.

48 T. D. Sharkey, Effects of moderate heat stress on photosynthesis: importance of thylakoid reactions, rubisco deactivation, reactive oxygen species, and thermotolerance provided by isoprene, Plant Cell Environ., 2005, 28, 269-277.

49 N. Suzuki and R. Mittler, Reactive oxygen species and temperature stresses: a delicate balance between signaling and destruction, Physiol. Plant., 126, 45-51.

50 M. Y. Roleda, C. Wiencke, D. Hanelt, W. H. van de Poll and A. Gruber, Sensitivity of Laminariales zoospores from Helgoland to ultraviolet and photosynthetically active radiation: implication for depth distribution and seasonal reproduction, Plant Cell Environ., 2005, 28, 466-479.

51 V. A. Gerard, K. DuBois and R. Greene, Growth responses of two Laminaria saccharina populations to environmental variation, Hydrobiologia, 1987, 151/152, 229-232.

52 B. de Reviers and F. Rousseau, Towards a new classification of the brown algae, Prog. Phycol. Res., 1999, 13, 107-201.

53 P. A. Wilson and R. D. Norris, Warm tropical ocean surface and global anoxia during the mid-Cretaceous period, Nature, 2001, 412, 425-429.

54 J. Zachos, M. Pagani, L. Sloan, E. Thomas and K. Billups, Trends, rhythms, and aberrations in global climate $65 \mathrm{Ma}$ to present, Science, 2001, 292, 667-671.

55 J. A. Raven, A. M. Johnston, J. E. Kübler, R. Korb, S. G. McInroy, L. L. Handley, C. M. Scrimgeour, D. I. Walker, J. Beardall, M. N. Clayton, M. Vanderklift, S. Fredriksen and K. H. Dunton, Seaweeds in cold seas: evolution and carbon acquisition, Ann. Bot., 2002, 90, 525-536.

56 C. E. Lane, C. Mayes, L. D. Druehl and G. W. Saunders, A multigene molecular investigation of the kelp (Laminariales, Phaeophyceae) supports substantial taxonomic reorganization, J. Phycol., 2006, 42, 493-512.

57 A. G. B. Poore and T. Fagerström, Intraclonal variation in macroalgae: causes and evolutionary consequences, Selection, 2000, 1-3, $123-133$.

58 V. D. Kreslavski, R. Carpentier, V. V. Klimov, N. Murata and S. I. Allakhverdiev, Molecular mechanisms of stress resistance of the photosynthetic apparatus, Biol. Membr., 2007, 24, 195-217.

59 D. Hanelt and M. Y. Roleda, UVB radiation may ameliorate photoinhibition in specific shallow-water tropical marine macrophytes, Aquat. Bot., 2009, DOI: 10.1016/j.aquabot.2008.12.005.

60 L. W. Jones and B. Kok, Photoinhibition of chloroplast reactions. I. Kinetics, and action spectra, Plant Physiol., 1966, 41, 1037-1043.

61 J. Grzymski, C. Orrico and O. M. Schofield, Monochromatic ultraviolet light induced damage to Photosystem II efficiency and carbon fixation in the marine diatom Thalassiosira pseudonana $(3 \mathrm{H})$, Photosynth. Res., 2001, 68, 181-192.

62 E. Turcsányi and I. Vass, Effect of UV-A radiation on photosynthetic electron transport, Acta Biol. (Szeged), 2002, 46, 171-173.

63 M. Richter, W. Rühle and A. Wild, Studies on the mechanism of Photosystem II photoinhibition I. A two-step degradation of D1protein, Photosynth. Res., 1990, 24, 229-235.

64 D. P. Häder and F. L. Figueroa, Photoecophysiology of marine macroalgae, Photochem. Photobiol., 1997, 66, 1-14. 
65 E. M. Purcell, Life at low Reynolds number, Am. J. Phys., 1977, 45, $3-11$.

66 M. Y. Roleda, M. N. Clayton and C. Wiencke, Screening capacity of UV-absorbing compounds in spores of Arctic Laminariales, J. Exp. Mar. Biol. Ecol., 2006, 338, 123-133.

67 C. Wiencke, M. Y. Roleda, A. Gruber, M. N. Clayton and K. Bischof, Susceptibility of zoospores to UV radiation determines upper depth distribution limit of Arctic kelps: evidence through field experiments, J. Ecol., 2006, 94, 455-463.
68 P. Müller, X.-P. Li and K. K. Niyogi, Non-photochemical quenching. A response to excess light energy, Plant Physiol., 2001, 125, 15581566.

69 I. Szabó, E. Bergantino and G. M. Giacometti, Light and oxygenic photosynthesis: energy dissipation as a protection mechanism against photo-oxidation, EMBO Rep., 2005, 6, 629-634.

70 J. D. Robison and M. E. Warner, Differential impacts of photoacclimation and thermal stress on the photobiology of four different phylotypes of Symbiodinium (Pyrrhophyta), J. Phycol., 2006, 42, 568-579. 